\title{
REVIEW \\ Assessment of Interprofessional Education (IPE) in Community Settings: A Systematic Review
}

\author{
Fatikhu Yatuni Asmara¹, Tri Nur Kristina², Diana Nur Afifah³, Dian Puspita Dewi² \\ ${ }^{1}$ Department of Nursing, Faculty of Medicine, Universitas Diponegoro, Indonesia \\ 2Department of Medicine, Faculty of Medicine, Universitas Diponegoro, Indonesia \\ 3Department of Nutrition Science, Faculty of Medicine, Universitas Diponegoro, Indonesia
}

\begin{tabular}{l} 
Article Info \\
\hline Article History: \\
Received: 14 November 2020 \\
Revised: 24 November 2021 \\
Accepted: 26 November 2021 \\
Online: 27 December 2021 \\
Keywords: \\
Assessment methods; assessment \\
tools; community setting; \\
competencies; Interprofessional \\
Education (IPE) \\
Corresponding Author: \\
Fatikhu Yatuni Asmara \\
Department of Nursing, Faculty of \\
Medicine, Universitas Diponegoro, \\
Indonesia \\
Email: f.y.asmara@fk.undip.ac.id
\end{tabular}

Email: f.y.asmara@fk.undip.ac.id

\begin{abstract}
Background: An assessment of methods and tools in interprofessional education (IPE) needs to be conducted to guarantee that the set learning objectives (LOs) or competencies are achieved, especially in community settings. This assessment is essential since in community settings, facilitators and students are not in the same frame, while direct observation is preferable in IPE. The implementation of methods and tools for assessment varies. Mostly, the assessment does not cover all competencies of IPE. Further identification of the way the assessment is conducted as well as the IPE competencies assessed is pivotal.

Purpose: This study aimed to review the implementation of IPE in community settings, especially the assessment conducted on the methods and tools used along with the assessors involved and the competencies achieved.

Methods: A systematic review was employed as a method in this study. Relevant articles from Science Direct, MEDLINE, CINAHL, and Scopus were screened based on the inclusion criteria: publication between 2010-2020, research and review articles, full-text articles, conducted in community settings, and involved assessment in acquiring the competencies. This review included 12 out of 1,273 screened articles. The articles were analyzed qualitatively by identifying the keywords, categories, and themes.

Results: The results showed the assessment conducted and the competencies achieved in IPE. The assessment included methods and tools as well as the assessors involved. Most existing studies used students' perceptions or reflections as the methods and involved less assessors such as supervisors or family members. Meanwhile, the assessment tools focused on certain competencies, such as roles and responsibilities, ethics and values, teamwork, and communication. However, no study assessed all competencies.

Conclusion: The analysis resulted in two large topics, i.e., the assessment, which includes the assessment methods and tools as well as assessors involved, and the competencies achieved. It is recommended to conduct further studies to develop objective assessment methods, comprehensive assessment tools, and generic competencies or learning outcomes.
\end{abstract}

How to cite: Asmara. F. Y., Kristina, T. N., Afifah, D. N., \& Dewi, D. P. (2021). Assessment of interprofessional education (IPE) in community settings: A systematic review. Nurse Media Journal of Nursing, 11(3), 318-335. https://doi.org/10.14710/nmjn.v11i3.34155

\section{Introduction}

Interprofessional Education (IPE) is increasingly viewed as essential to health care education and is associated with an increase in the quality of care through the improvement of the behaviors of the health care team in conducting collaboration (Riskiyana et al., 2018). IPE is a learning process in which students from various health disciplines collaborate to provide health care services to patients with the goal of enhancing the quality of care (Kelly, 2010). IPE is a form of collaboration which can be practiced by students in delivering health care services (Horder, 2004; McPherson et al., 2001; Perkin, 2011). Collaborations and teamwork should be introduced to the students in the academic phase before exposure in the clinic as they build a culture of collaboration and communication (Curran et al., 2010). Many studies show that IPE has a positive effect on students when it is implemented during the pregraduate phase. It contributes to improved teamwork (Wagner et al., 2011); collaboration, coordination, holistic intervention, patient management, and services (Opina-Tan, 2013); improved skills, knowledge, and attitudes toward collaboration (Claramita et al., 2014); strong confidence in communication (Carr, 2015); and understanding of roles and responsibilities (Hammick et al., 2007). 
IPE is a learning approach, and thus, its outcomes or competencies need to be assessed. Interprofessional Education Collaborative (IPEC) issued details on IPE competencies, namely values/ethics for interprofessional practice, roles/responsibilities, interprofessional communication, and teams and teamwork (Schmitt et al., 2011). However, some studies stated that the competencies could be broader such as for teamwork, roles and responsibilities, communication, learning/reflection, patient, and ethics/attitudes (Thistlethwaite \& Moran, 2010). Meanwhile, some studies only focus on specific competence, such as collaboration (Haruta et al., 2019; Findyartinia et al., 2019).

Furthermore, in the assessment, both methods and tools are employed to guarantee that the set learning objectives (LOs) or competencies of IPE are achieved. It can be conducted for formative and summative purposes. Formative assessment is conducted during IPE to give feedback to students so they can improve their performance while summative assessment gives a final score and decides the students' achievement of LOs (Oktay et al., 2017). For example, selfreported assessment and assessment based on students' reports can be applied in IPE (Allvin et al., 2020; Lapkin et al., 2013). However, the assessment needs to use objective measurement to identify the achievement of learning outcomes rather than just students' self-assessment (Shumway \& Harden, 2003; Anderson \& Kinnair, 2016). Furthermore, an integrative portfolio can be used as a formative assessment (Anderson \& Kinnair, 2016) and mentoring for students (Mollahadi et al., 2018) because it invites feedback from peers and supervisors which can help improve students' performance (Bok et al., 2013; Driessen et al., 2007). However, IPE in the community needs specific attention because supervisors cannot stand by along with students as they would in the clinical setting. Thistlethwaite et al. (2014) stated that direct observation is the most preferable method in IPE assessment; however, the limited opportunities for students and facilitators make it hardly viable to commence. Some studies reported that IPE along with the assessment therefor has been implemented in hospitals. McCharty et al. (2014) implemented IPE in hospitals for maternal acute illness management. It involved students doing self-reflection in identifying the changing roles of health professionals (doctors, nurses, and midwives). Meanwhile, Walker et al. (2014) involved supervisors or trainers to assess teamwork improvement during the training of obstetric and neonatal emergencies. This is why IPE needs a comprehensive assessment that involves many sources to ensure that students master the competencies. Epstein (2007) and Oktay et al. (2017) stated that the involvement of many sources in IPE assessment renders the process more objective. It is also emphasized by Thistlethwaite (2012) that one of the biggest challenges for interprofessional educators is to develop assessment for IPE outcomes, particularly teamwork and skills for collaborative practice.

Knowledge about IPE assessment, especially its process and competencies in the community setting, is limited. Shrader et al (2017) investigated assessment tools used to evaluate IPE's learning outcomes in the pharmacy education setting, while Riskiyana et al. (2018) conducted a systematic review to investigate IPE outcomes. For that reason, this study is conducted to investigate the assessment for methods and tools applied as well as the assessors involved in the comprehensive assessment of IPE implementation particularly in the community setting. A suitable assessment method that involves many sources is preferable since it makes the process more objective (Almoghirah et al., 2021). It is important to investigate the assessment as there is a limited number of publications that covers a tool that can be used to assess all competencies (Almoghirah et al., 2021; Shrader et al., (2017). Finally, the assessment has considerable potential to drive learning (Wiliam, 2011). A validated and reliable assessment method and tool will encourage students to participate in a quality learning process and master competencies. Accordingly, this review aimed to investigate IPE implementation in the community settings, including assessment methods and tools used, assessors involved and competencies achieved. Two research questions were posed in this study, including: (1) How is the assessment of IPE (including the way the methods and tools are used and the way the stakeholders/assessors are involved) conducted? and (2) What are the competencies or learning outcomes achieved?

\section{Methods}

2.1 Research design

A systematic review was implemented as a method in this study. It helped to identify the existing studies on the same topic and to extract them to create a conclusion. Furthermore, it was 
determined using PICO (Population, Intervention, Context, and Outcomes) following specific criteria as shown in Tabel 1.

Table 1. Description of PICO

\begin{tabular}{ll}
\hline Population & $\begin{array}{l}\text { Health care students and facilitators exposed to IPE (nursing, } \\
\text { medical, midwifery, nutrition) }\end{array}$ \\
\hline Intervention & Assessment of IPE \\
\hline Context & IPE program in the community setting \\
\hline Outcomes & $\begin{array}{l}\text { Reflection of IPE implementation including the assessment } \\
\text { methods and tools used along with the assessors involved and } \\
\text { the competences achieved }\end{array}$ \\
\hline
\end{tabular}

2.2 Search methods

The existing electronic databases were used to search the articles, including Science Direct, CINAHL, MEDLINE, and Scopus. They can be accessed in the digital library of the university. Articles were identified using Boolean operator 'and' and 'or' to combine the keywords;

1. interprofessional education $\$$

2. health student\$

3. nursing

4. medicine

5. midwive $\$$

6. midwifery

7. Assessment

8. Method\$

9. Tool\$

10.competencies

11. community.

\subsection{Inclusion and exclusion criteria}

The relevant articles were selected by applying the inclusion and exclusion criteria. These articles were published between 2010-2020, were research and review articles, could be accessed as full texts, focused on the assessment methods and tools, and covered studies implemented in a community setting. Articles covering IPE implementation in clinical settings were excluded. The articles used were only those published within ten years to ensure their relevance. For articles screening, the PRISMA flowchart (Figure 1) was used. The process was broken down into four steps, namely identification, screening, eligibility validation, and inclusion (Page et al., 2021).

\subsection{Screening for articles}

Rayyan $\AA$ software was used to screen the articles. Three authors (FYA, DNA, and DPD) identified the title, abstract, and keywords by applying the inclusion criteria after duplications were removed. The process was then continued with the identification of full articles. The review was conducted independently. Disagreement during the review was settled through consultation with the fourth author (TNK).

\subsection{Data extraction}

The articles selected (12 articles) were examined qualitatively through the identification process based on some information, i.e., title \& author, objectives, setting, design, assessment methods, assessment tools, assessors, and competencies. Keywords and themes were extracted from the articles. Three authors (FYA, DNA, and DPD) identified all included articles based on the foregoing categories and summarized them in a table (Table 3, see Appendix 1).

\subsection{Quality appraisal}

Critical appraisal needed to be conducted in a systematic review as it identifies the quality of the studies covered therein (Aromataris et al., 2015). Table 2 shows the result of the critical appraisal conducted in this study. The process was conducted by two authors (FYA and TNK). Six studies were verified using a checklist of quasi-experiment studies; three studies were verified 
using a checklist of qualitative studies; and three used mix-method studies. The answer of yes was scored 1, while the answer of no, unclear, and not applicable was scored 0 . The scores were interpreted based on a study by Reilly et al. (2016), which indicates that studies are good if the total score is $>80 \%$, fair if the total score is $50-80 \%$, and poor if the total score is $<50 \%$.

Table 2. Level of critical appraisal

\begin{tabular}{clc}
\hline No & \multicolumn{1}{c}{ Author, year } & Critical appraisal \\
\hline 1 & Opina-Tan (2013) & Good \\
2 & Housley et al. (2018) & Good \\
3 & Gallagher et al. (2015) & Fair \\
4 & Soliman et al. (2012) & Fair \\
5 & Haruta et al. (2018) & Fair \\
6 & Haruta et al. (2019) & Good \\
7 & Ryan et al. (2015) & Fair \\
8 & Sullivan et al. (2015) & Good \\
9 & Dressel et al. (2017) & Good \\
10 & Randita et al. (2019) & Good \\
11 & Findyartinia et al. (2019) & Fair \\
12 & Walker et al. (2019) & Fair \\
\hline
\end{tabular}

\subsection{Data analysis}

Nine steps of synthesis without meta-analysis (SWiM) in a systematic review (Chambell et al., 2020) was used as guidance in data analysis. Step 1 is grouping the studies. The selected studies were grouped under several items namely author \& year, objectives, setting, design, assessment methods, assessment tools, assessors, and competencies. Steps 2-6 were conducted to answer review questions. The similarities and differences especially related to the assessment methods, assessment tools, assessors involved, and competencies acquired were identified. The findings were formulated based on the keywords for the categories. The findings were categorized under two major themes namely assessment process and competencies acquired. The findings were then put in the table, indicating the groups of the studies and themes (step 7). The presentation and discussion of the results and identification of limitations made up the steps 8 and 9, respectively. Furthermore, the recommendation for further research or better IPE implementation was proposed.

\section{Results}

\subsection{Characteristics of the selected studies}

Twelve articles were selected in the screening process. These articles were identified based on certain criteria, such as author \& year, objectives, setting, design, assessment methods, assessment tools, assessors, and competencies (Table 3). Nine of the 12 articles covered a study conducted in the community setting (Housley et al., 2018; Gallagher et al., 2015; Soliman et al., 2012; Haruta et al., 2018; Haruta et al., 2019; Ryan et al., 2015; Sullivan et al., 2015; Dressel et al., 2017; Randita et al., 2019; Findyartinia et al., 2019), two articles covered a study conducted in rural or community hospitals or clinics (Haruta et al., 2019; Walker et al., 2019), and one article covered a study conducted in a family setting (Opina Tan, 2013). Additionally, most studies were conducted using a quantitative method (Soliman et al., 2012; Haruta et al., 2019; Ryan et al., 2015; Sullivan et al., 2015; Dressel et al., 2017; Randita et al., 2019), while Opina-Tan (2013), Findyartinia et al. (2019), Walker et al. (2019) used mix method and Housley et al. (2018), Gallagher et al. (2015), and Haruta et al. (2018) applied qualitative research.

The PRISMA flowchart was applied to describe the process of article selection until their final inclusion (Figure 1). 


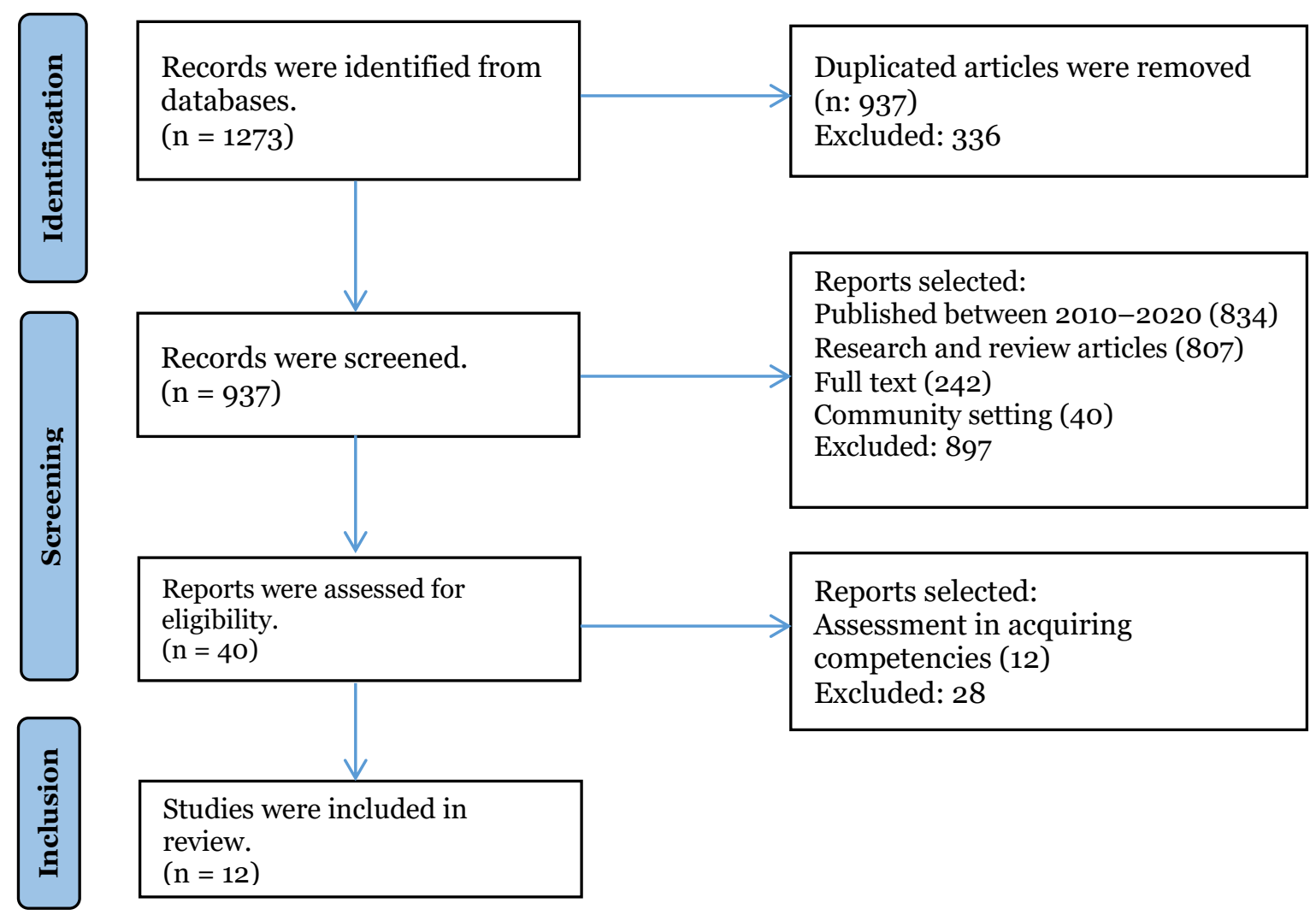

Figure 1. Study selection process

According to Figure 1, it can be seen that 1,273 articles were found during the identification process through the application of keywords (stage 2) using four electronic search engines (Science Direct, MEDLINE, CINAHL, and Scopus). Then, certain criteria were used to screen the articles. About 834 articles were published between 2010-2020, 807 articles were research or review articles, and 242 articles could be accessed as full texts. The next step was identifying the setting of the study; 40 studies were implemented in the community setting. The last step was the eligibility validation. Twelve out of 40 articles focusing on the assessment of the acquired competencies were included as final articles. Finally, the results were analyzed qualitatively through keywords, categories, and themes (Table 4).

\subsection{Assessment process}

Based on the results, the assessment process was divided into three components, namely assessment tools, assessment methods, and assessors or persons who assess the students. There were two types of assessment tools namely quantitative standardized assessment tool (Opina Tan, 2013; Haruta et al., 2019; Sullivan et al., 2015; Dressel et al., 2017; Findyartinia et al., 2019; Randita et al., 2019; Ryan et al., 2015) and qualitative tools (Housley et al., 2018; Gallagher et al., 2015; Haruta et al., 2018; Findyartinia et al., 2019; Walker et al., 2019). Ten of the twelve studies involved students in doing the assessment, while the rest invited health care providers as assessors (Haruta et al., 2018; Findyartinia et al., 2019). In addition to assessment tools, assessment methods were implemented in two ways namely self-reflection or self-assessment and discussion through Focus Group Discussion (FGD). 
Table 4. Synthesis of findings

\begin{tabular}{|c|c|c|}
\hline Finding 1 (keywords) & Finding 2 (Categories) & Finding 3 (Themes) \\
\hline Family Case Management Questionnaires (FCMQ) & \multirow[t]{10}{*}{ Assessment tools } & \multirow[t]{19}{*}{ Assessment process } \\
\hline Written reflective statements & & \\
\hline Questionnaires for survey & & \\
\hline $\begin{array}{l}\text { Assessment of Interprofessional Team Collaboration } \\
\text { Scale (AITCS) }\end{array}$ & & \\
\hline $\begin{array}{llll}\text { Students Attitudes } & \text { Toward } & \text { Community } & \text { Service } \\
\text { Survey } & & & \\
\end{array}$ & & \\
\hline 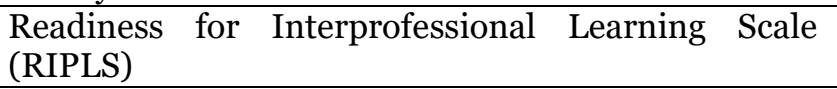 & & \\
\hline 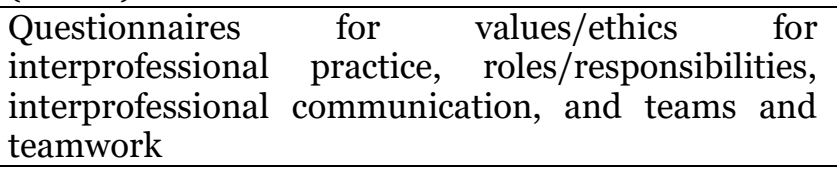 & & \\
\hline Intercollaborator Assessment Rubric & & \\
\hline Collaborative Practice Assessment Tool (CPAT) & & \\
\hline $\begin{array}{llll}\text { Readiness for } & \text { Interprofessional } & \text { Learning } & \text { Scale } \\
\text { (RIPLS) } & & & \\
\text { IEPS }\end{array}$ & & \\
\hline Self-reflection & \multirow[t]{5}{*}{ Assessment methods } & \\
\hline Self-administered & & \\
\hline Group discussion & & \\
\hline Observation & & \\
\hline Personal interviews & & \\
\hline Students & \multirow[t]{4}{*}{ Assessor } & \\
\hline Supervisor & & \\
\hline Community provider & & \\
\hline Health professions & & \\
\hline Learning about collaboration & \multirow[t]{5}{*}{ Collaboration } & \multirow{28}{*}{$\begin{array}{l}\text { Competencies } \\
\text { assessed }\end{array}$} \\
\hline Collaborative practice in the rural IPE program & & \\
\hline Working in interprofessional teams & & \\
\hline Collaboration & & \\
\hline Collaborative practice & & \\
\hline Appreciation of roles & \multirow{19}{*}{$\begin{array}{l}\text { Roles and } \\
\text { responsibilities }\end{array}$} & \\
\hline Holistic care & & \\
\hline Service to the community & & \\
\hline Living with and learning from each other & & \\
\hline Skill teaching & & \\
\hline Knowledge sharing & & \\
\hline Self discovery & & \\
\hline Role discovery & & \\
\hline health is a holistic concept & & \\
\hline Patient-/client-/family-/community-centered & & \\
\hline Role contribution & & \\
\hline A nursing profession & & \\
\hline $\begin{array}{l}\text { Incorporating patients' beliefs and personal beliefs } \\
\text { into medical care }\end{array}$ & & \\
\hline $\begin{array}{l}\text { To explain the roles and responsibilities of other care } \\
\text { providers }\end{array}$ & & \\
\hline Works together to provide care & & \\
\hline Roles and responsibilities & & \\
\hline Collaborative patient-centered approach & & \\
\hline patient-involvement & & \\
\hline The roles of other professions & & \\
\hline Communicating with patients & \multirow[t]{4}{*}{ Ethics and values } & \\
\hline Sensitivy to diversity & & \\
\hline Barriers to healthcare & & \\
\hline Greater job satisfaction & & \\
\hline
\end{tabular}


Table 4. Continued

\begin{tabular}{|c|c|c|}
\hline Finding 1 (keywords) & Finding 2 (Categories) & Finding 3 (Themes) \\
\hline \multicolumn{3}{|l|}{$\begin{array}{l}\text { To place the interests of patients and populations } \\
\text { at the center of interprofessional healthcare } \\
\text { delivery. }\end{array}$} \\
\hline \multicolumn{3}{|l|}{$\begin{array}{l}\text { Socio-cultural factors such as uncertainty, } \\
\text { avoidance tendency, power differentials, and } \\
\text { collectivist culture }\end{array}$} \\
\hline Teamwork building & Team and teamwork & \\
\hline \multicolumn{3}{|l|}{ Facilitation of relationships } \\
\hline \multicolumn{3}{|l|}{ Better relationships with neighboring facilities } \\
\hline \multirow{2}{*}{\multicolumn{3}{|c|}{ Working with diverse communities and patients, }} \\
\hline & & \\
\hline \multicolumn{3}{|l|}{$\begin{array}{l}\text { Integrating the knowledge and experience of other } \\
\text { professions }\end{array}$} \\
\hline \multicolumn{3}{|l|}{ Appropriate to the specific care situation } \\
\hline \multicolumn{3}{|l|}{ To inform care decisions } \\
\hline \multicolumn{3}{|l|}{$\begin{array}{l}\text { Respecting patient and community values and } \\
\text { priorities/preferences for care. }\end{array}$} \\
\hline \multicolumn{3}{|l|}{ Team functioning } \\
\hline \multicolumn{3}{|l|}{ Leadership and vision-mission-aims } \\
\hline \multicolumn{3}{|l|}{ Decision-making } \\
\hline \multicolumn{3}{|l|}{ Enhanced interprofessional engagement } \\
\hline Interprofessional communication & Communication & \\
\hline \multicolumn{3}{|l|}{ Reflection } \\
\hline \multicolumn{3}{|l|}{ Understanding of others } \\
\hline \multicolumn{3}{|l|}{ Skill in listening actively } \\
\hline \multicolumn{3}{|l|}{$\begin{array}{l}\text { Encouraging ideas and opinions of other team } \\
\text { members }\end{array}$} \\
\hline \multicolumn{3}{|l|}{ Conflict management } \\
\hline \multicolumn{3}{|l|}{ Communication } \\
\hline Unique learning experience & Learning experience & \\
\hline \multicolumn{3}{|l|}{ Learning in the workplace } \\
\hline \multicolumn{3}{|l|}{$\begin{array}{l}\text { Quality of a positive learning ambiance for } \\
\text { students }\end{array}$} \\
\hline Observing role modeling in the workplace & & \\
\hline
\end{tabular}

\subsection{Competencies acquired}

All studies investigated the competencies acquired during the implementation of the IPE program. The competencies achieved varied. According to Table 4, there were mostly five competencies investigated, namely collaboration (Opina Tan, 2013; Soliman et al., 2012; Randita et al., 2019; Walker et al., 2019); ethics and values (Housley et al., 2018; Haruta et al., 2019; Findyartinia et al., 2019); roles and responsibilities (Opina Tan, 2013; Gallagher et al., 2015; Housley et al., 2018; Haruta et al., 2018; Haruta et al., 2019; Ryan et al., 2015; Randita et al., 2019; Walker et al., 2019); team and teamwork (Housley et al., 2018; Haruta et al., 2018; Haruta et al., 2019, Sullivan et al., 2015; Dressel et al., 2017; Randita et al., 2019; Findyartinia et al., 2019; Walker et al., 2019); communication (Housley et al., 2018; Haruta et al., 2018; Randita et al., 2019); and learning experience (Opina Tan, 2013; Gallagher et al., 2015; Walker et al., 2019). Some studies covered several competencies. No study covered all competencies in its assessment.

\section{Discussion}

This study aimed to review the implementation of IPE in community settings, especially related to the IPE assessment and competencies achieved. Two general themes were resulted, namely assessment and competencies that are further discussed in this section. The assessment involves assessment method, assessment tool, and assessors, while the competencies consist of six elements, i.e., collaboration, roles and responsibilities, ethics and values, communication, team and teamwork, and learning experiences. 


\section{1 Assessment}

The assessment is concluded as a theme based on the assessment methods, assessment tools, and assessor categories (Table 3). Mostly, the assessment method involves students as the individual participant who gives response during assessment such as self-assessment or selfadministered assessment (Opina Tan, 2013; Soliman et al., 2012; Haruta et al., 2019; Ryan et al., 2015; Dressel et al., 2017) and group discussion about students' reflection on IPE implementation (Housley et al., 2018; Gallagher et al., 2015; Haruta et al., 2018; Sullivan et al., 2015; Findyartinia et al., 2019; Walker et al., 2019). Further, there are two studies which involved supervisors to do an assessment (Haruta et al., 2018; Findyartinia et al., 2019). Self-assessment and group discussions make up a single assessment method which engages students as a subject of assessment. However, this method needs to involve more than one assessment subject to ensure a higher level of objectivity in the process (Epstein, 2007). It is recommended to involve many assessors in the assessment of IPE.

Multisource Feedback (MSF) is a method that can be applied to ensure the objective assessment of IPE as it involves students, peers, and patients to give feedback (Epstein, 2007; Riveros et al., 2016). Furthermore, MSF can be applied in formative and summative assessments (Davis et al., 2009; Kiessling et al., 2017). When applied in formative assessment, students will be given feedback so they can improve their performance (Oktay et al., 2017). However, some studies stated that MSF is applied for a single profession. For instance, Davies and Archer (2005) stated that doctors who lacked self-confidence could be helped by MSF and were then able to develop communication with patients and colleagues (Kiessling et al., 2017). Meanwhile, Asmara and Santoso (2015) stated that MSF is an effective assessment method to improve the professional behavior of nursing students. Considering the benefits of MSF and its feasibility, it is suggested to implement MSF as an assessment method for IPE implementation. This initiative is echoed by McKenzie et al. (2014), who noted that MSF not only prompts the students but also program designers, such as faculty members and supervisors to reflect on their collaboration process.

This review also showed that the assessment tools used in the existing studies vary. They used questionnaires or a set of questions to assess IPE learning outcomes or competencies. For instance, Haruto et al. (2019) used questionnaires of Assessment of Interprofessional Team Collaboration Scale (AITCS) and Findyartinia et al. (2019) used the Collaborative Practice Assessment Tool (CPAT) to assess collaborative competencies, whereas Ryan et al. (2015) used questionnaires of the Students Attitudes toward Community Service survey to gather data on the students' experience related to interprofessional competencies. On the other hand, open-ended questions were used to encourage students to give descriptive responses. This type of question was used by Dressel et al. (2017) to assess students' achievement on IPE competencies. Meanwhile, Housley et al. (2018) applied written reflective statements to describe learning outcomes in interprofessional practice. A questionnaire is more precise to assess the achievement of LOs or competencies because it is more valid and reliable than qualitative tools. Even though open-ended questions used as guidance during the group discussion can elaborate on students' reflection, this type of question has a lower degree of validity and reliability. Some studies used a combination of two tools, namely questionnaires and open-ended questions; however, this combination only identified one of the IPE competency domains (Opina-Tan, 2013; Findyartinia et al., 2019; Walker et al., 2019).

The majority of the existing studies assessed only a single competence. For instance, Haruta et al. (2019), Randita et al. (2019), and Findyartinia et al. (2019) assessed collaboration as an achieved IPE competence, while Walker et al. (2019) and Sullivan et al. (2015) used the Readiness for Interprofessional Learning Scale (RIPLS) to assess students' readiness to join IPE program. However, Dressel et al. (2017) assessed four competencies according to IPEC (2011).

Developing an assessment tool that is applicable for all IPE competencies in the community setting or primary health care is important (Vyt, 2017). A comprehensive assessment tool containing all IPE competencies will help both students and supervisors to identify the achievement.

\section{2 Competencies}

As shown in Table 4, competencies are divided into collaboration, roles and responsibilities, ethics and values, communication, team and teamwork, and learning experience. The existing studies used competencies by IPEC (2011) in their assessment namely Values/Ethics for 
Interprofessional Practice, Roles/Responsibilities, Interprofessional Communication, and Teams and Teamwork (Housley et al., 2018; Dressel et al., 2017). Shannon et al. (2017) and Dole et al. (2021) supported the finding that communication and teamwork are important in a team of people across health professions. Furthermore, Taekman et al. (2017) stated that roles and responsibilities of each health profession could be learnt through IPE. It was elaborated by Schmitt et al. (2011) that Values/Ethics for Interprofessional Practice is the ability to work with other professions to build a climate of mutual respect and shared values, while Roles and Responsibilities means giving health services based on patients and the community's needs using the knowledge of single profession's roles and other professions. Furthermore, communication with patients, families, communities, and people of other health professions as a team in the attempt to help patients solve their health problems is the focus of Interprofessional Communication, while implementation of values and principles of the team to assess, plan, and deliver treatment to patients, families, and communities is the focus of Teams and Teamwork competencies. Some studies covered broader competencies. For instance, Randita et al. (2019) added team functioning and conflict management as competencies of the IPE program in the community setting. However, other studies only focused on certain competencies. For instance, collaboration was the main competency of the IPE program in the study by Haruta et al. (2019) and Findyartinia et al. (2019), while Walker et al. (2019) added observing role model as a learning experience, and Opina-Tan (2013) stated gaining unique learning experience as an IPE competency.

Competencies of the IPE program in a community setting need to be set to be more specific and generic, so they can be used in all IPE implementations. Generic LOs will be a guide for students and supervisors in IPE implementation. Perron et al. (2014) stated that clinical skills needed in IPE implementation in the community setting, more specific in the gathering and assessment of information, cover performing a physical examination using clinical reasoning and judgment. Clinical reasoning and interprofessional behavior, which are parts of interprofessional attitudes and perceptions, have also been recommended to be included in IPE competencies by Seif et al. (2014). Furthermore, Oelke et al. (2013) argued that cultural competencies can be included as competencies in Interprofessional Collaboration Practice in the relationship between health care providers and patients or community or among them. It will support the competencies in interprofessional communication.

IPE is a learning process in which students from various health disciplines collaborate to provide health care services to patients and its goal is to increase the quality of care. Many studies have shown that IPE has a positive effect on students when it is implemented during undergraduate training. IPE contributes to improved collaboration, coordination, patient management, holistic intervention, and services (Opina-Tan, 2013). It is also associated with better skills, knowledge, and attitudes in collaboration (Claramita et al., 2017), strong confidence in communication (Carr, 2015), and understanding of roles and responsibilities (Hammick et al., 2007). Therefore, IPE needs to be implemented in the academic phase before students join an internship.

However, it is important to set the ideal IPE assessment components. They are assessment and competencies. Generic and specific competencies or learning objectives need to be defined, so they can be used widely in the community setting. Then, the assessment, including assessment methods and tools, needs to be improved. Objective assessment methods are preferable to evaluate students' achievement on IPE competencies, while a comprehensive assessment tool is needed to realize a better assessment.

\section{Implications and limitations}

The result of this review implies on the assessment of the learning process, especially IPE. There are varieties of methods and tools offered to assess students' achievement on IPE competencies. Faculty members can develop and modify the program based on the results. Furthermore, the assessment process, including methods, tools, and assessors, can be implemented in other subjects, for instance, nursing. However, competencies are specifics for each subject. Therefore, it needs to adjust to the learning objectives.

This review has limitations. The included articles were limited to those published in English to accommodate the language competencies of the authors. Further reviews may consider articles that are published in other languages, since researchers can publish studies in languages other 
than English. Furthermore, the identification of the included studies was focused on research and review articles. In the future, grey articles can be included as some reports of IPE programs may not be published in journals.

\section{Conclusion}

This review concludes that IPE assessment involves several factors, namely assessment and competencies. Methods, tools, and assessors make up the assessment part while collaboration, roles, and responsibilities, ethics and values, communication, team and teamwork, and learning experience make up the competencies acquired by the students who join the IPE program. Even though the assessment methods used varies, it is recommended to use more than one method in order to render the assessment more objective. Furthermore, assessors should include teachers or facilitators to give scores. Self-assessment is a preferable method to encourage students to do self-reflection. In addition, students can also observe a role model in clinical practice to enrich their learning experience.

\section{Acknowledgment}

The authors would like to thank the Institute of Research and Community Services of Universitas Diponegoro for providing the funding for this study.

\section{Author contribution}

FYA: Screening and analysis of the articles, manuscript preparation, manuscript revision; DNA: Analysis of the articles, DPD: Analysis of the articles, TNK: Analysis of the articles, manuscript preparation.

\section{Conflict of interest} study.

All authors stated that there is no conflict of interest while conducting and publishing the

\section{References}

Allvin, R., Thompson, C., Edelbring, S. 2020. Assessment of interprofessional competence in undergraduate health professions education: Protocol for a systematic review of self-report instruments. Systematic Review, 9(142). http://doi.org/10.1186/s13643-020-01394-7

Almoghirah, H., Nazar, H., \& Illing, J., (2021). Assessment tools in pre-licensure interprofessional education: A systematic review, quality appraisal dan narrative synthesis. Medical Education, 55, 795-807. http://doi.org/10.1111/medu.14453

Anderson, E. S., \& Kinnair, D. (2016). Integrating the assessment of interprofessional education into the health care curriculum. Journal of Taibah University Medical Sciences, 11(6), 552558. http://doi.org/10.1016/j.jtumed.2016.10.005

Aromataris, E., Fernandez, R., Godfrey, C., Holly, C., Kahlil, H., \& Tungpunkom, P. (2015). Summarizing systematic reviews: Methodological development, conduct and reporting of an umbrella review approach. International Journal Evidence Based Healthcare, 13(3), 132140. http://doi.org/10.1097/XEB.0000000000000055

Asmara, F. Y., \& Santoso, A. (2015). The effectivity of Multi Source Feedback (MSF) to assess Professional Behaviour (PB) of nursing students: An evaluation study. Nurse Media Journal of Nursing, 5(2), 101 - 108. http://doi.org/10.14710/nmjn.v5i2.10536

Campbell, M., McKenzie, J. E., Sowden, A., Katikireddi, S. V., Brennan, S. E., Ellis, S., HartmannBoyce, J., Ryan, R, Shepperd, S., Thomas, J., Welch, V., \& Thomson, H. (2020). Synthesis without meta-analysis (SWiM) in systematic review. The BMJ, 1-6. http://doi.org/10.1136/bmj.l6890

Carr, S. (2015). Examining health professional students' attitudes on interprofessional education. (Publication no. 309) [Doctoral Dissertations, University of Rhode Island]. http://digitalcommons.uri.edu/oa_diss/309

Curran, V.R., Sharpe, D., Flynn, K., \& Button, P. (2010). A longitudinal study of the effect of an interprofessional education curriculum on students' satisfaction and attitudes towards interprofessional teamwork and education. Journal of Interprofessional Care, 24(1), 41-52. http://doi.org/10.3109/13561820903011927 
Davies, H. \& Archer, J. (2005). Multi source feedback: Development and practical aspects. The Clinical Teacher, 2(2), 77-81. http://doi.org/10.1111/j.1743-498X.2005.00064.x

Davis, M.H., Ponamperuma, G.G., \& Wall, D. (2009). Workplace-based assessment. In: Dent, J.A \& Harden, R.M. (eds). A practical guide for medical teachers. Elsevier Limited.

Delunas, L. R \& Rouse, S. (2014). Nursing and medical students' attitude about communication and collaboration before and after an interprofessional education experience. Nursing Education Perspective, 35(2), 100-105. http://doi.org/10.1111/j.1365-2923.2011.04143.x

Dole, D., Farley, CL., Sokas, R. K., \& Kesler, J. L. (2021). Partnering to support education for midwives and nurses in liberia. Nursing for Women's Health, 25(1), 82-92. http://doi.org/10.1016/j.nwh.2020.11.002

Dressel, A., Mkandawire-Valhmub, L., Dietrichc, A., Chirwad, E., Mgawaderee, F., Kambalametoref, S., \& Kakob, P. (2017). Local to global: Working together to meet the needs of vulnerable communities. Journal of Interprofessional Care, 31(5), 667-669

Driessen, E., Van Tartwijk, J., Van Der Vleuten, C., \& Wass, V. (2007). Portfolios in medical education: Why do they meet with mixed success? A systematic review. Medical Education, 41(12), 1224-1233. http://doi.org/10.1080/13561820.2017.1329717

Epstein, R. M. (2007). Assessment in medical education. New England Journal of Medicine, 356(4), 387-396. http://doi.org/10.1056/NEJMra054784

Findyartinia, A., Kambey, D. R., Yusra, R. Y., Timor, A. B., Khairania, C. D., Setyorini, D., \& Soemantri, D. (2019). Interprofessional collaborative practice in primary healthcare settings in Indonesia: A mixed-methods study. Journal of Interprofessional Education \& Practice, 17, 100279. http://doi.org/10.1016/j.xjep.2019.100279

Gallagher, P., Pullon, S., Skinner, M., McHugh, P., McKinlay, E., \& Gray, L. (2015). An interprofessional community education project as a socially accountable assessment. Journal of Interprofessional Care, 29(5), 509-511. http://doi.org/10.3109/13561820.2015.1004040

Hammick, M., Freeth, D., Koppel, I., Reeves, S., \& Barr, H. (2007). A best evidence systematic review of interprofessional education: BEME guide no. 9. Medical Teacher, 28(9), 735-751. http://doi.org/10.1080/01421590701682576

Haruta, J., Ozone, S., \& Goto, R. Factors for self-assessment score of interprofessional team collaboration in community hospitals in Japan. Family Medicine Community Health, 7. eo00202. http://doi.org/10.1136/fmch-2019-000202

Haruta, J., Yoshida, K., Goto, M., Yoshimoto, H., Ichikawa, S., Morid, Y., Yoshimie, K., \& Otsukaf, M. (2018). Development of an interprofessional competency framework for collaborative practice in Japan. Journal of Interprofessional Care, 32(4), 436-443. http://doi.org/10.1080/13561820.2018.1426559

Horder, J. (2004). Inter-professional collaboration and interprofessional education. British Journal of General Practice, 54(501), 243-245.

Housley, C. L., Neill, K. K., White, L. S., Tedder, A. T., \& Castleberry, A. N. (2018). An evaluation of an interprofessional practice-based learning environment using student reflections. Journal of Interprofessional Care, 32(1), 108-110. http://doi.org/10.1080/13561820.2017.1356808

Kelly, P. J. (2010). Interprofessional education activity with doctorate of pharmacy \& PA students at Mercer University. https://paeaonline.org/?ht\%3Aa\%2Fgetdocumentaction\%2Fi\%2F116159

Kiessling, C., Tsimtsiou, Z., Essers, G., Nuland, M., Anvik, T., Bujnowska-Fedak, M. M., Hovey, R., Joakimsen, R., Perron, N. J., Rosenbaum, M., \& Silverman, J. (2017). General principles to consider when designing a clinical communication assessment program. Patient Education and Counseling, 10o, 1762-1768. http://doi.org/10.1016/j.pec.2017.03.027

Lapkin, S., Levett-Jones, T., \& Gilligan, C. (2013). A systematic review of the effectiveness of interprofessional education in health professional programs. Nurse Education Today, 33(2), 90-102. http://doi.org/10.1016/j.nedt.2011.11.006

MacKenzie, D. E., Doucet, S., Nasser, S., Godden-Webster, A. L., Andrews, C., \& Kephart, G. (2014). Collaboration behind-the-scenes: Key to effective interprofessional education. Journal of Interprofessional Care, 28(4), 381-383. http://doi.org/10.3109/13561820.2014.890923

McCharty, R., Byrne-Davis, L., Hart, J., Yuill, G., Slattery, H., Jackson, M., Byrne, G. J. (2014). A feasible, acceptable and effective way to teach health care workers in low- and middle income 
countries a method to manage acutely. Midwifery, 31, 19-24. http://doi.org/10.3109/13561820.2014.890923

McPherson, K. (2001). Working and learning together: Good quality care depends on it, but how can we achieve it?. BMJ Quality and Safety, 10(2), 46-53. http://doi.org/10.1136/qhc.0100046

Mollahadi, M., Khademolhoseini, S. M., \& Khaghanizadeh, M. (2018). The portfolio as a tool for mentoring in nursing students: A scoping review. Iranian Journal of Nursing and Midwifery Research, 23(4), 241-247. http://doi.org/10.4103/ijnmr.IJNMR_195_17

Oelke, N. D., Thurston, W. E., \& Arthur, N. (2013) Intersections between interprofessional practice, cultural competency and primary healthcare. Journal of Interprofessional Care, 27(5), 367-372. http://doi.org/10.3109/13561820.2013.785502

Oktay, C., Senol, Y., Rinnert, S., \& Cete, Y. (2017). Utility of 360-degree assessment of residents in a Turkish academic emergency medicine residency program. Turkish Journal of Emergency Medicine, 17, 12-15. http://doi.org/10.1016/j.tjem.2016.09.007

Opina-Tan, L. A. (2013). A pilot implementation of inter-professional education in a community academe partnership in the Philippines. Education for Health. 26(3), 164-171. http://doi.org/10.4103/1357-6283.125992

Page, M. J, Moher, D., Bossuyt, P. M, Boutron, I., Hoffmann, T. C., Mulrow, C. D., Shamseer, L., Tetzlaff, J. M., Akl, E. A., Brennan, S. E., Chou, P., Glanville, J., Grimshaw, J. M., Hróbjartsson, A., Lalu, M. M., Li, T., Loder, E. W., Mayo-Wilson, E., McDonald, S., McGuinness, L. A., ... McKenzie, J. E. 2021. PRISMA 2020 explanation and elaboration: Updated guidance and exemplars for reporting systematic reviews. $B M J, 372$, n160. http://doi.org/10.1136/bmj.n16o

Perkin, K. (2011). Nurse practitioners and interprofessional collaboration. Journal of Interprofessional Care, 25, 243-244. http://doi.org/10.3109/13561820.2011.586244

Randita, A. B. T., Widyandana, W., \& Claramita, M. (2019). IPE-COM: A pilot study on interprofessional learning design for medical and midwifery students. Journal of Mutidiscipline Health Care, 12: 767-775. http://doi.org/10.2147/JMDH.S2O2522

Reilly, R., Evans, K., Gomersall, J., Gorham, G., Peters, M. D. J., Warren, S., O’Shea, R., Cass, A., \& Brown, A. (2016). Effectiveness, cost effectiveness, acceptability and implementation barriers/enablers of chronic kidney disease management programs for Indigenous people in Australia, New Zealand and Canada: A systematic review of mixed evidence. BMC Health Services Research, 16, 119. https://doi.org/10.1186/s12913-016-1363-0

Riskiyana, R., Claramita, M., \& Rahayu, G. R. (2018). Objectively measured interprofessional education outcome and factors that enhance program effectiveness: A systematic review. Nurse Education Today, 66, 73-78. http://doi.org/10.1016/j.nedt.2018.04.014

Riveros, R., Kimatian, S., Castro, P., Dhumak, V., Honar, H., Mascha, E.J., \& Sessler, D.I. (2016). Multisource feedback in professionalism for anesthesia residents. Journal of Clinical Anesthesia , 34, 32-40. http://doi.org/10.1016/j.jclinane.2016.03.038

Ryan, M., Vanderbilt, A. A., Mayer, S. D., \& Gregory, A. (2015). Interprofessional education as a method to address health needs in a Hispanic community setting: A pilot study. Journal of Interprofessional Care, 29(5), 515-517. http://doi.org/10.3109/13561820.2015.1020360

Sakai, I., Yamamoto, T., Takahashi Y., Maeda, T., Kunii, Y., \& Kurokoch, K. (2017). Development of a new measurement scale for interprofessional collaborative competency: The Chiba Interprofessional Competency Scale (CICS29). Journal of Interprofessional Care, 31(1), 5965. http://doi.org/10.1080/13561820.2016.1233943

Schmitt, M., Blue, A., Aschenbrener, C. A., \& Viggiano, T. R., (2011). Core competencies for interprofessional collaborative practice: Reforming health care by transforming health professionals' education. Academic $\quad$ Medicine, $86 \quad$ (11). http://doi.org/10.1097/ACM.obo13e3182308e39

Sedyowinarso, M., \& Claramita, M. (2014). Interprofessional education (IPE), communication and interprofessional teamwork. In Y. S. Prabandari, F. Tetradewi, F. Fitriana (Eds.), Buku Acuan Umum CFHC-IPE [General guideline book of CFHC-IPE] (pp. 17-35). Fakultas Kedokteran Universitas Gajah Mada.

Seif, G., Coker-Bolt, P., Kraft, S., Gonsalves, W., Simpson, K., \& Johnson, E. (2014). The development of clinical reasoning and interprofessional behaviors: Service-learning at a 
student-run free clinic. Journal of Interprofessional Care, 28(6), 559-564, http://doi.org/10.3109/13561820.2014.921899

Shannon, D. W. (2017, January 7). Case study: How team training helped support rural obstetrics. American Association for Physician Leadership. https://www.physicianleaders.org/news/case-study-how-team-training-helped-supportrural-obstetrics

Shrader, S. Farland, M. Z., Danielson, J., Sicat, B., \& Umland, E. M. (2017). A systematic review of assessment tools measuring interprofessional education outcomes relevant to pharmacy education. American Journal of Pharmaceutical Education, 81(6), 119. http://doi.org/10.5688/ajpe816119

Shumway, J. M., \& Harden, R. M., (2003). AMEE guide no.25: The assessment of learning outcomes for the component and reflective physician. Medical Technology, 25(6), 569-584. http://doi.org/10.1080/0142159032000151907

Soliman, S. R., MacDowell, M., Schriever, A. E., Glasser, M \& Schoen, M. D. (2012). An interprofessional rural health education program. American Journal of Pharmaceutical Education, 76(10), 199. http://doi.org/10.5688/ajpe7610199

Solomon, P., \& Salfi, J. (2011). Evaluation of an interprofessional education communication skills initiative. Education for Health, 24(2), 616.

Sullivan, K., Charrette, A., Massey, C., Bartlett, D., Walker, C., Bond, I., Davies, P. B., Scheidt, N. A., \& Fong, J. J., (2015). Interprofessional education with a community fall prevention event. $\begin{array}{llll}\text { Journal of Interprofessional } & \text { 29(4), }\end{array}$ http://doi.org/10.3109/13561820.2014.969834

Taekman, J. M., Foureman, M. F., Bulamba, F., Steele, M., Comstock, E., Kintu, A., Mauritz, A., \& Olufolabi, A. (2017). A novel multiplayer screen-based simulation experience for African learners improved confidence in management of postpartum hemorrhage. Frontier in Public Health, 5, 248. http://doi.org/10.3389/fpubh.2017.00248

Thistlethwaite, J., Dallest, K., Moran, M., Dunston, R., Roberts, C., Eley, D., Bogossian, F., Forman, D., Bainbridge, L., Drynan, D., \& Fyfe, S. 2014. Introducing the individual Teamwork Observation and Feedback Tool (iTOFT): Development and description of a new interprofessional teamwork measure. Journal of Interprofessional Care, 30(4), 526-528. http://doi.org/10.3109/13561820.2016.1169262

Thistlethwaite, J. E, \& Moran, M. (2010). Learning outcomes for Interprofessional Education (IPE): Literature review and synthesis. Journal of Interprofessional Care, 24, 503-513. http://doi.org/10.3109/13561820.2010.483366

Thistlethwaite, J. (2012). Interprofessional Education: A review of context, learning and the research agenda. Medical Education, 46, 58-70. http://doi.org/10.1111/j.13652923.2011.04143.x

Vyt, A. (2017). Development and validation of a questionnaire to self-assess the quality of interprofessional team meetings in primary and community healthcare. Journal of Interprofessional Care, 31(2), 140-146. http://doi.org/10.1080/13561820.2016.1269058

Wagner, J., Liston, B., \& Miller, J. (2011). Developing interprofessional communication skills. Teaching and Learning in Nursing, 6(3), 97-101. http://doi.org/10.1016/j.teln.2010.12.003

Walker, L. E., Cross, M., \& Barnett, T. (2019). Students' experiences and perceptions of interprofessional education during rural placement: A mixed methods study. Nurse Education Today, 75, 28-34. http://doi.org/10.1016/j.nedt.2018.12.012

Wiliam, D. (2011). What is assessment for learning. Studies in Educational Evaluation, 3, 3-14. http://doi.org/10.1016/j.stueduc.2011.03.001

Yamamoto, T., Sakai, I., Takahashi, Y., Maeda, T., Kunii, Y., \& Kurokochi, K. (2014). Development of a new measurement scale for interprofessional collaborative competency: A pilot study in Japan. Journal of Interprofessional Care, 28(1). http://doi.org/10.3109/13561820.2013.851070 
Table 3. The summary of the reviewed studies

\begin{tabular}{|c|c|c|c|c|c|c|c|c|}
\hline No & $\begin{array}{l}\text { Author \& } \\
\text { Year }\end{array}$ & Objective & Setting & Design & $\begin{array}{l}\text { Assessment } \\
\text { Method }\end{array}$ & Assessment Tools & Participants & Competencies \\
\hline 2 & $\begin{array}{l}\text { Housley et } \\
\text { al. (2018) }\end{array}$ & $\begin{array}{l}\text { Describing the } \\
\text { learning } \\
\text { outcomes in an } \\
\text { interprofessional } \\
\text { practice } \\
\text { environment }\end{array}$ & Community & $\begin{array}{l}\text { Qualitative } \\
\text { method } \\
\text { Written } \\
\text { reflective } \\
\text { statements } \\
\text { were } \\
\text { analyzed by } \\
3 \\
\text { researchers } \\
\text { as coders }\end{array}$ & $\begin{array}{l}\text { Self- } \\
\text { reflection }\end{array}$ & $\begin{array}{l}\text { Written reflective } \\
\text { statements }\end{array}$ & $\begin{array}{l}\text { Students } \\
\text { (medicine, } \\
\text { nursing, } \\
\text { dentistry, } \\
\text { physiotherapy, } \\
\text { pharmacy, } \\
\text { and dietetics) }\end{array}$ & $\begin{array}{l}\text { Mastering IPE } \\
\text { competencies: roles and } \\
\text { responsibilities (skill } \\
\text { teaching, knowledge } \\
\text { sharing, self-discovery, role } \\
\text { discovery), ethics and } \\
\text { values (communicating } \\
\text { with patients, sensitivity to } \\
\text { diversity, barriers to health } \\
\text { care), interprofessional } \\
\text { communication (teamwork } \\
\text { building), team and team } \\
\text { works (teamwork building) }\end{array}$ \\
\hline 3 & $\begin{array}{l}\text { Gallagher } \\
\text { et al. } \\
\text { (2015) }\end{array}$ & $\begin{array}{l}\text { Exploring } \\
\text { participants' } \\
\text { response to IPE }\end{array}$ & Community & $\begin{array}{l}\text { Qualitative } \\
\text { method }\end{array}$ & $\begin{array}{l}\text { Focus Group } \\
\text { Discussion } \\
\text { (FGD) and } \\
\text { personal } \\
\text { interview }\end{array}$ & $\begin{array}{l}\text { Questions for FGD } \\
\text { and personal } \\
\text { interview }\end{array}$ & $\begin{array}{l}75 \text { students } \\
\text { and } 12 \\
\text { community } \\
\text { providers }\end{array}$ & $\begin{array}{l}\text { Identifying the importance of } \\
\text { learning in the work place, } \\
\text { identifying the impact of } \\
\text { students living with and } \\
\text { learning from each other, } \\
\text { enabling health as a holistic } \\
\text { concept, and identifying the } \\
\text { influence of the quality of a } \\
\text { positive learning ambiance } \\
\text { for students. }\end{array}$ \\
\hline
\end{tabular}


Table 3. Continued

\begin{tabular}{|c|c|c|c|c|c|c|c|c|}
\hline No & $\begin{array}{c}\text { Author \& } \\
\text { Year }\end{array}$ & Objective & Setting & Design & $\begin{array}{l}\text { Assessment } \\
\text { Method }\end{array}$ & Assessment Tools & Participants & Competencies \\
\hline 4 & $\begin{array}{l}\text { Soliman et } \\
\text { al. (2012) }\end{array}$ & $\begin{array}{l}\text { Developing, } \\
\text { implementing, } \\
\text { and assessing } \\
\text { an } \\
\text { interprofessional } \\
\text { rural health } \\
\text { professions } \\
\text { program for } \\
\text { pharmacy and } \\
\text { medical } \\
\text { students }\end{array}$ & $\begin{array}{l}\text { Rural } \\
\text { communities }\end{array}$ & $\begin{array}{l}\text { Quantitative } \\
\text { method }\end{array}$ & $\begin{array}{l}\text { Self- } \\
\text { administered }\end{array}$ & $\begin{array}{l}\text { Questionnaires for } \\
\text { survey }\end{array}$ & $\begin{array}{l}\text { Year 1: } 22 \\
\text { students (6 } \\
\text { pharmacy and } \\
16 \text { medical) } \\
\text { Year 2: } 26 \\
\text { students ( } 8 \\
\text { pharmacy and } \\
18 \text { medical) }\end{array}$ & $\begin{array}{l}\text { Realizing collaborative } \\
\text { practice in the rural IPE } \\
\text { program }\end{array}$ \\
\hline 5 & $\begin{array}{l}\text { Haruta et } \\
\text { al. (2018) }\end{array}$ & $\begin{array}{l}\text { Developing an } \\
\text { interprofessional } \\
\text { competency } \\
\text { framework for } \\
\text { Japanese health } \\
\text { care } \\
\text { professionals }\end{array}$ & Community & $\begin{array}{l}\text { Qualitative } \\
\text { method }\end{array}$ & $\begin{array}{l}\text { Group } \\
\text { discussion }\end{array}$ & $\begin{array}{l}\text { Questions for } \\
\text { group discussion } \\
\text { Prototype to be } \\
\text { developed }\end{array}$ & $\begin{array}{l}\text { Health care } \\
\text { providers }\end{array}$ & $\begin{array}{l}\text { Mastering two core domains } \\
\text { of competencies namely } \\
\text { "patient-/client-/family- } \\
\text { /community-centered } \\
\text { approach" and } \\
\text { "Interprofessional } \\
\text { communication", and four } \\
\text { peripheral domains of "role } \\
\text { contribution", "facilitation of } \\
\text { relationships", "reflection" } \\
\text { and "understanding of } \\
\text { others". }\end{array}$ \\
\hline 6 & $\begin{array}{l}\text { Haruta et } \\
\text { al. (2019) }\end{array}$ & $\begin{array}{l}\text { Exploring the } \\
\text { factors } \\
\text { associated with } \\
\text { self-assessment } \\
\text { score of } \\
\text { interprofessional } \\
\text { collaboration in } \\
\text { community } \\
\text { hospitals }\end{array}$ & $\begin{array}{l}\text { Community } \\
\text { hospital }\end{array}$ & $\begin{array}{l}\text { Cross } \\
\text { sectional } \\
\text { method }\end{array}$ & $\begin{array}{l}\text { Self- } \\
\text { assessment }\end{array}$ & $\begin{array}{l}\text { Assessment of } \\
\text { Interprofessional } \\
\text { Team } \\
\text { Collaboration } \\
\text { Scale (AITCS). }\end{array}$ & $\begin{array}{l}325 \text { of } 630 \\
\text { students }\end{array}$ & $\begin{array}{l}\text { Understanding the factors } \\
\text { affecting IPC namely younger } \\
\text { age, mastering nursing } \\
\text { profession, building better } \\
\text { relationships with } \\
\text { neighboring facilities, and } \\
\text { realizing greater job } \\
\text { satisfaction }\end{array}$ \\
\hline
\end{tabular}


Table 3. Continued

\begin{tabular}{|c|c|c|c|c|c|c|c|c|}
\hline No & $\begin{array}{c}\text { Author \& } \\
\text { Year }\end{array}$ & Objective & Setting & Design & $\begin{array}{l}\text { Assessment } \\
\text { Method }\end{array}$ & Assessment Tools & Participants & Competencies \\
\hline 7 & $\begin{array}{l}\text { Ryan et al. } \\
\text { (2015) }\end{array}$ & $\begin{array}{l}\text { Gathering } \\
\text { student } \\
\text { perceptions } \\
\text { about their } \\
\text { interprofessional } \\
\text { experience }\end{array}$ & Community & $\begin{array}{l}\text { A pre/post } \\
\text { intervention } \\
\text { design }\end{array}$ & $\begin{array}{l}\text { Students' } \\
\text { retrospective } \\
\text { assessments }\end{array}$ & $\begin{array}{l}\text { The Students } \\
\text { Attitudes Toward } \\
\text { Community } \\
\text { Service survey }\end{array}$ & $\begin{array}{l}17 \text { of } 50 \\
\text { students }\end{array}$ & $\begin{array}{l}\text { Ensuring students can be } \\
\text { more comfortable in } \\
\text { working with diverse } \\
\text { communities and patients } \\
\text { as well as in } \\
\text { interprofessional teams and } \\
\text { incorporating patients' } \\
\text { beliefs and personal beliefs } \\
\text { into medical care }\end{array}$ \\
\hline 8 & $\begin{array}{l}\text { Sullivan et } \\
\text { al. (2015) }\end{array}$ & $\begin{array}{l}\text { Developing an } \\
\text { IPE opportunity } \\
\text { through a } \\
\text { community fall } \\
\text { prevention } \\
\text { event and } \\
\text { assessing } \\
\text { changes in } \\
\text { students' } \\
\text { attitudes toward } \\
\text { IPE after } \\
\text { participation in } \\
\text { the event }\end{array}$ & Community & $\begin{array}{l}\text { A pre-post } \\
\text { intervention }\end{array}$ & $\begin{array}{l}\text { reflective } \\
\text { activity }\end{array}$ & $\begin{array}{l}\text { Readiness for } \\
\text { Interprofessional } \\
\text { Learning Scale }\end{array}$ & $\begin{array}{l}46 \text { of } 63(73 \% \\
\text { response rate) } \\
\text { (16 pharmacy, } \\
17 \text { physical } \\
\text { therapy, } 12 \\
\text { nursing, and } 18 \\
\text { physician } \\
\text { assistants) } \\
\text { students }\end{array}$ & $\begin{array}{l}\text { Realizing positive } \\
\text { improvement toward } \\
\text { greater receptiveness of IPE } \\
\text { and interprofessional } \\
\text { teamwork }\end{array}$ \\
\hline 9 & $\begin{array}{l}\text { Dressel et } \\
\text { al. (2017) }\end{array}$ & $\begin{array}{l}\text { Assessing how } \\
\text { the students } \\
\text { achieve the } \\
\text { interprofessional } \\
\text { collaborative } \\
\text { practice core } \\
\text { competencies }\end{array}$ & Community & $\begin{array}{l}\text { A quasi- } \\
\text { experimental } \\
\text { pre/post- } \\
\text { intervention } \\
\text { study design }\end{array}$ & $\begin{array}{l}\text { Self- } \\
\text { administered }\end{array}$ & $\begin{array}{l}\text { Questionnaires } \\
\text { consisting of } \\
\text { questions that refer } \\
\text { to values/ethics for } \\
\text { interprofessional } \\
\text { practice, roles/ } \\
\text { responsibilities, } \\
\text { interprofessional } \\
\text { communication, } \\
\text { and teams and } \\
\text { teamwork }\end{array}$ & $\begin{array}{l}\text { 10 participating } \\
\text { students }\end{array}$ & $\begin{array}{l}\text { Realizing improvement on } \\
\text { values/ethics for } \\
\text { interprofessional practice, } \\
\text { roles/responsibilities, and } \\
\text { teams and teamwork, not } \\
\text { only in the interprofessional } \\
\text { communication }\end{array}$ \\
\hline
\end{tabular}


Table 3. Continued

\begin{tabular}{|c|c|c|c|c|c|c|c|c|}
\hline No & $\begin{array}{l}\text { Author \& } \\
\text { Year }\end{array}$ & Objective & Setting & Design & $\begin{array}{l}\text { Assessment } \\
\text { Method }\end{array}$ & Assessment Tools & Participants & Competencies \\
\hline 10 & $\begin{array}{l}\text { Randita et } \\
\text { al. (2019) }\end{array}$ & $\begin{array}{l}\text { Conducting a } \\
\text { pilot study of } \\
\text { Interprofessional } \\
\text { Education- } \\
\text { Community } \\
\text { (IPE-COM) for } \\
\text { medical and } \\
\text { midwifery } \\
\text { students }\end{array}$ & Community & $\begin{array}{l}\text { A one-group } \\
\text { pre- } \\
\text { experimental } \\
\text { study with a } \\
\text { pre- and } \\
\text { post-test }\end{array}$ & $\begin{array}{l}\text { Assessment } \\
\text { from } \\
\text { supervisor }\end{array}$ & $\begin{array}{l}\text { Intercollaborator } \\
\text { Assessment Rubric }\end{array}$ & $\begin{array}{l}15 \text { medical } \\
\text { students and } 19 \\
\text { midwifery } \\
\text { students }\end{array}$ & $\begin{array}{l}\text { Ensuring six IPE competence } \\
\text { are measured during the } \\
\text { assessment: (1) } \\
\text { communication, (2) } \\
\text { collaboration, (3) roles and } \\
\text { responsibilities, (4) team } \\
\text { functioning, (5) collaborative } \\
\text { patient-centered approach, } \\
\text { and (6) conflict management }\end{array}$ \\
\hline 11 & $\begin{array}{l}\text { Findyartinia } \\
\text { et al. (2019) }\end{array}$ & $\begin{array}{l}\text { Identifying the } \\
\text { perceptions of } \\
\text { IPCP } \\
\text { implementation } \\
\text { and exploring } \\
\text { the challenges } \\
\text { and barriers } \\
\text { associated with } \\
\text { socio-cultural } \\
\text { values and } \\
\text { other factors } \\
\text { that could } \\
\text { potentially } \\
\text { affect the } \\
\text { implementation } \\
\text { of IPCP }\end{array}$ & Community & Mix method & $\begin{array}{l}\text { Self- } \\
\text { administered }\end{array}$ & $\begin{array}{l}\text { Collaborative } \\
\text { Practice } \\
\text { Assessment Tool } \\
\text { (CPAT) for } \\
\text { quantitative data } \\
\text { and Focus Group } \\
\text { Discussion for } \\
\text { qualitative data }\end{array}$ & $\begin{array}{l}290 \text { of } 303 \\
\text { health } \\
\text { professionals } \\
\text { (61.8\% } \\
\text { response rate) } \\
\text { Nine focus } \\
\text { group } \\
\text { discussions } \\
\text { involving } 73 \\
\text { health } \\
\text { professionals }\end{array}$ & $\begin{array}{l}\text { Assessing the mastery of } \\
\text { competencies namely } \\
\text { leadership and vision- } \\
\text { mission-aims decision- } \\
\text { making and patient- } \\
\text { involvement, identifying } \\
\text { socio-cultural factors such as } \\
\text { uncertainty avoidance } \\
\text { tendency, power differentials, } \\
\text { and collectivist culture. } \\
\text { Themes for FGD: structures, } \\
\text { supporting factors, inhibiting } \\
\text { factors, perceived benefits, } \\
\text { and challenges of IPCP. }\end{array}$ \\
\hline 12 & $\begin{array}{l}\text { Walker et } \\
\text { al. (2019) }\end{array}$ & $\begin{array}{l}\text { Identifying } \\
\text { students' } \\
\text { perceptions } \\
\text { toward and } \\
\text { readiness for }\end{array}$ & $\begin{array}{l}\text { Rural } \\
\text { clinical }\end{array}$ & $\begin{array}{l}\text { Mix method } \\
\text { Survey for } \\
\text { IPE } \\
\text { questions }\end{array}$ & $\begin{array}{l}\text { Self- } \\
\text { administered }\end{array}$ & $\begin{array}{l}\text { RIPLS, IEPS for } \\
\text { survey }\end{array}$ & $\begin{array}{l}60 \\
\text { undergraduate } \\
\text { health care } \\
\text { students from } \\
\text { allied health, }\end{array}$ & $\begin{array}{l}\text { Observing role modelling in } \\
\text { the workplace and learning } \\
\text { about collaborative practice } \\
\text { and the roles of other } \\
\text { professions, and identifying }\end{array}$ \\
\hline
\end{tabular}


Nurse Media Journal of Nursing, 11(3), 2021, 335

Table 3. Continued

\begin{tabular}{|c|c|c|c|c|c|c|c|}
\hline No & $\begin{array}{l}\text { Author \& } \\
\text { Year }\end{array}$ & Objective & Design & $\begin{array}{l}\text { Assessment } \\
\text { Method }\end{array}$ & Assessment Tools & Participants & Competencies \\
\hline & & $\begin{array}{l}\text { interprofessional } \\
\text { education in the } \\
\text { rural clinical } \\
\text { learning } \\
\text { environment in } \\
\text { one region of } \\
\text { Australia }\end{array}$ & & $\begin{array}{l}\text { Group } \\
\text { discussion }\end{array}$ & $\begin{array}{l}\text { Focused IPE } \\
\text { questions for FGD }\end{array}$ & $\begin{array}{l}\text { medicine, } \\
\text { nursing and } \\
\text { midwifery. }\end{array}$ & $\begin{array}{l}\text { professions, and identifying } \\
\text { activities that enhance } \\
\text { interprofessional } \\
\text { engagement }\end{array}$ \\
\hline
\end{tabular}

